that speculation is premature. The time when speculative theory and observational research may profitably go hand in hand is when the possibilities, or at any rate the probabilities, can be narrowed down by experiment, and the theory can indicate the tests by which the remaining wrong paths may be blocked up one by one.

The mathematical physicist is in a position of peculiar difficulty. He may work out the behaviour of an ideal model of material with specifically defined properties, obeying mathematically exact laws, and so far his work is unimpeachable. It is no more speculative than the binomial theorem. But when he claims a serious interest for his toy, when he suggests that his model is like something going on in Nature, he inevitably begins to speculate. Is the actual bcdy really like the ideal model? May not other unknown conditions intervene? He cannot be sure, but he cannot suppress the comparison; for it is by looking continually to Nature that he is guided in his choice of a subject. A common fault, to which he r'ust often plead guilty, is to use for the comparison data over which the more experienced observer shakes his head; they are too insecure to build extensively upon. Yet even in this, theory may help observation by showing the kind of data which it is especially important to improve.

I think that the more idle kinds of speculation will $b \geq$ avoided if the investigation is conducted from the right point of view. When the properties of an ideal model have been worked out by rigorous mathematics, all the underlying assumptions being clearly understood, then it becomes possible to say that such-andsuch properties and laws lead precisely to such-andsuch effects. If any other disregarded factors are present, they should now betray themselves when a comparison is made with Nature. There is no need for disappointment at the failure of the model to sive perfect agreement with observation; it has served its purpose, for it has distinguished what are the features of the actual phenomena which require new conditions for their explanation. A general preliminary agreement with observation is necessary, otherwise the model is hopeless; not that it is necessarily wrong so far as it goes, but it has evidently put the less essen- tial properties foremost. We have been pulling at the wrong end of the tangle, which has to be unravelied by a different approach. But after a general agreement with observation is established, and the tanyle begins to loosen, we should always make ready tor the next knot. I suppose that the applied mathematician whose theory has just passed one still more stringent test by observation ought not to feel satisfaction, but rather disappointment-"Foiled again! This time I had hoped to find a discordance which would throw light on the points where my model ciuld be improved." Perhaps that is a counsel of perfection; I own that I have never felt very keenly a disappointment of this kind.

Our model of Nature should not be like a building - a handsome structure for the populace to admire, until in the course of time someone takes away a corner-stone and the edifice comes toppling down. It should be like an engine with movable parts. We need not fix the position of any one lever; that is to be adjusted from time to time as the latest observations indicate. The aim of the theorist is to know the train of wheels which the lever sets in motion-that binding of the parts which is the soul of the engine.

In ancient days two aviators procured to themselves wings. Dædalus flew safely through the middle air across the sea, and was duly honoured on his landing. Young Icarus soared upwards towards the sun until the wax which bound his wings melted, and his flight ended in fiasco. In weighing their achievements perhaps there is something to be said for Icarus. The classic authorities tell us that he was only "doing a stunt," but I prefer to think of him as the man who certainly brought to light a constructional defect in the flying-machines of his day. So, too, in science. Cautious Dædalus will apply his theories where he feels most confident they will safely go; but by his excess of caution their hidden weaknesses cannot be brought to light. Icarus will strain his theories to the breaking-point until the weak joints gape. For a spectacular stunt? Perhaps partly; he is often very human. But if he is not yet destined to reach the sun and solve for all time the riddle of its constitution, yet he may hope to learn from his journey some hints to build a better machine.

\title{
Memorial Tributes to Sir Norman Lockyer.
}

$\mathrm{T}^{\mathrm{N}}$ Sir Norman Lockyer the country loses one of 1 the most ardent supporters of science in his time. As one who enjoyed his intimate friendship for more than half a century, I would fain add my personal contribution to the many expressions of regret and appreciation which the loss is sure to call forth.

There never was a man more thoroughly imbued than he with a sense of the importance of the cultivation of science, not only for its own sake, but also for the multitude of ways in which it may be made to minister to the welfare of mankind. Though he had made choice of astronomy as his own field of work, he was no mere specialist, but kept his sympathy in touch with the progress of science as a whole, and worked, harder than most of his contemporaries knew, to further that progress. Sir Norman's younger years as a clerk in the War Office, while affording him an insight into the methods of a Government Department, furnished also a training in business NO. 2653 , VOL. IO6] habits which served him in good stead through later life. The secretaryship of the Duke of Devonshire's Commission on scientific instruction, to which as a young man he was appointed, undoubtedly gave the impetus that made him so strenuous an advocate of a wider recognition of the claims of science for a place in our educational and industrial organisation. This appointment, by bringing him into personal acquaintance with the leading men of science of the day, strengthened and widened his sympathies. One of the first results of the experience thus gained was to convince him of the need for better teaching of the rudiments of science in our schools. $\mathrm{He}$ saw that one of the first requirements was the production of simple elementary treatises on the different departments of natural knowledge, written not by mere book-makers, but by the best living authorities on the several subjects. He confided to me the scheme which he drew up, and asked me to co-operate with him. It so happened 
that a similar proposal was about the same time laid before Mr. Alexander Macmillan, head of the publishing firm, by Profs. Huxley, Balfour Stewart, and Roscoe. It was finally arranged that the scheme of these eminent professors should be adopted, and that Lockyer and I should contribute to it. In this way arose the series of elementary text-books or Primers, of which millions of copies have been sold, some of them having been translated into most of the languages of Europe and into some of those of Asia.

Sir Norman's energy also led him to project a weekly journal entirely devoted to science. He convinced the same enterprising publisher that such a journal would be of much value in chronicling for the general public the progress of scientific opinion and discovery. Thus the present publication came into existence. Lockyer was, of course, its editor, and he continued to fill the editorial chair with amazing industry and success for fifty years. It would be difficult to appraise the value of this service to the cause of science. But the historian of the future, when he comes to describe the various influences which have fostered that cause in this country since I870, will not forget to include Sir Norman and NATURE.

My old friend's enthusiasm spurred him to take part in a long succession of solar eclipse expeditions, which took him into remote parts of the world, and sometimes involved no little risk. These foreign journeys he continued to undertake until he was not far from seventy years of age.

Sir Norman Lockyer's many communications to the Royal Society and other learned bodies, and also the array of his separately published volumes, form the best monument of his life-work. Those who knew him best often wondered how, with only one serviceable eye, he could get through the amount of telescopic and spectroscopic work which he accomplished. His personal charm was great. The kindly nature, ready helpfulness, and infectious enthusiasm that were so characteristic of him endeared him to those who had the privilege of his friendship, and who feel that he leaves a vacant place among the men of science in this country which it will be hard to fill as he filled it. Arch. Geikie.

WirH the death, at an advanced age, of Joseph Norman Lockyer, a remarkable and in some respects unique personality passes away from the English scientific world. It would be unnecessary for me, even if I were competent, to describe the progress and achievements of his work in science; that has been done already in these pages; nor need I dwell on merely biographical detail. I have been invited to write an appreciation of Lockyer. I can only respond by giving my impression of the man drawn from tolerably close intimacy in an acquaintanceship extending over half a century. Some biographical detail is a necessary framework.

NO. 2653 , VOL. IO6]
Lockyer's education, though doubtless sufficient, seems to have been unsystematic; part was obtained on the Continent, where he attended lectures at the Sorbonne. He did not receive the training either of a public school or of a university; he started in life unhampered by any educational shibboleths or the acquirement of academic status. This was amply made up to him in after-life, for it is more than doubtful if any contemporary man of science had more honorary degrees showered upon him. Lockyer's father was a man of scientific occupation and probably of some attainment; the son evidently received from him an impulse towards science which no schooling in the early half of the last century could have supplied.

At the age of twenty-one Lockyer was appointed to a clerkship in the War Office; there he remained for thirteen years. Hundreds of young men in such a position have merely matured or withered towards a pension. From that fate he was preserved by the tumultuous energy which characterised him all through life. In the face of opposition he carried out internal administrative reforms in the Office, and had his reward in 1865 in being appointed by Lord de Grey editor of the Army Regulations. I remember his telling me that their codification cost him two years' work, and that the strain of having to carry in his head for the purpose a vast mass of detail almost broke him down. It seems almost incredible that, apart from his official life, he was able to carry on successful astronomical research. He was elected to the Royal Astronomical Society in 1860 , and in r866 devised a method of observing the solar prominences without an eclipse; this was afterwards applied by Janssen and himself, and commemorated in a medal by the French Government. In 1868 he discovered in the sun helium, then unknown as a terrestrial element. In 1869 , while still in the War Office, he was elected into the Royal Society.

With such a record of administrative and scientific ability it is not surprising to find Lockyer in the following year appointed secretary of the Royal Commission on Scientific Instruction. At its conclusion Disraeli transferred him to the Science and Art Department, for which he organised the extremely successful Loan Exhibition of Scientific Apparatus opened by Queen Victoria in 1876 . In I88I he became professor of astronomical physics in the Royal College of Science. Research into solar phenomena now became the dominant purpose of his life; it led him into fertile speculations in various directions. They engaged him to the last, and but a year ago he contributed a paper to this journal. The earliest was the correlation between climate and solar activity. I well remember the cold douche he administered when he pointed out to me that its effect, far from being direct, might be the reverse. The importance of this principle, which at the time seemed paradoxical, has now become fundamental in meteorological research; regions are now known to be affected oppositely by changes in the sun's 
heat supply. Lockyer was chief of eight Government eclipse expeditions in which a brief examination of the isolated chromosphere became possible. In these he had the assistance of the Navy, and their success.was due not only to his capacity for leadership and organisation, but also to his ability to inspire interest and enthusiasm in the work in both officers and bluejackets. The installation of a temporary observatory in some remote and uninhabited spot was not seldom difficult.

In 1869 Lockyer and Alexander Macmillan founded NATURE; English science in other respects owes much to the latter and his successors. Henry Woodward, who is still with us, was present at a dinner at the Garrick Club to celebrate its birth. It needed a good send-off, for Sir H. Trueman Wood thought that at the time it "can scarcely have been regarded as a very promising speculation." Probably it was not, but both founders-and Lockyer the most-had a different aim. It may be permitted to quote from the present Vice-Chancellor of the University of Leeds a record of how it has been attained:"The exacting care with which it has been edited, the impartiality and precision of its judgments, the wide range of its information, the accuracy of its reports, have given NATURE in its own sphere unique distinction and authority."

As to the first, I remember hearing from a distinguished man of science that at a dinner party at which both he and Lockyer were guests, the latter received an urgent printer's proof in the middle of dinner and corrected it then and there.

Lockyer's service with the Commission on Scientific Instruction gave him a thorough insight into the resources, or rather lack of them, throughout the country. It is certainly true, as the present Vice-Principal of Birmingham University tells us, that through the columns of NATURE "there has appeared an informed and helpful criticism that has furthered university growth and development." The criticism was sometimes pretty vigorous. Henry Smith, at Oxford, himself a mathematician of European fame, thought that the editor rather trespassed on the creative function of the Author of Nature.

At Oxford Henry Acland had devoted the best years of his life to getting biology and chemistry admitted to the medical curriculum. Tireless energy with "aeterna mansuetudine" succeeded not merely in this, but also in the erection of the New Museum, which was opened in I86I. This, with its Venetian gothic and Skidmore ironwork, is a shrine rather than a laboratory. It was, in fact, an outcome of the Oxford æsthetic renaissance, which in turn owed its filiation to the "Oxford movement." So far science was in the best of company with Dr. Pusey in its support. But Acland really only wanted biology and chemistry for his medical school; accordingly we find in the New Museum Rolleston overtaxing his strength in the attempt to cover the whole biological field; Brodie, emancipated from the cellar of the Ashmolean, treating inorganic chemistry with NO. 2653, VOL. IO6] originality and freshness; and Vernon Harcourt working at chemical change in a reproduction of the Glastonbury kitchen. This was excellent, but unfortunately it was all. As to the rest of the science faculty, some never lectured, some were physically incapacitated, some were frankly nonresident. Much has changed since; new professorships have been founded and entrusted to men of assured accomplishment; new laboratories have been built; and the present Vice-Chancellor finds it convenient occasionally to borrow a number of NATURE to verify an appointment.

At Cambridge we have the testimony of Dr. Glaisher as to "the almost complete lack of interest in natural science that existed in the university when NATURE was founded"; even in mathematics "there was no encouragement-quite the reverse-to research of any kind." To the "great expansion of thought, study, and learning" that has taken place since, "NATURE has largely and worthily contributed."

These testimonials, borrowed from the record on the occasion of last year's jubilee, acquire a true significance when we read in them LOCKyer for NATURe. He never ceased to insist on the necessity of combining university teaching with research. He displeased the somnolent, and still more when he supported a better distribution of available funds in which the untimely death of Dr. Appleton deprived him of support from the side of the "humanities." $\mathrm{He}$ was in no way deterred by the sarcasm of Henry Smith and Sir John Evans-who ought to have known better-that the endowment of research only camouflaged-to use the phrase of the day-the research for endowment.

We may congratulate ourselves with Sir Donald MacAlister that NATURE "still informs, chastens, and stimulates the scientific worker and the scientific teacher." Chastening is now seldom called for, but in the early days it was vigorously applied. Teaching and text-books were largely obsolete, and received criticism that was often ruthless. Controversies in its pages were sometimes fierce; they cleared things up, and Lockyer kept the ring with complete impartiality. He would himself submit to a little chastening without ill-will. On one occasion a series of articles was commenced with a general approval from Huxley. But it immediately became apparent that the fundamental assumption was unsound. I sent him a short statement of the fact; he admitted that it was unanswerable, published it, and stopped the series.

If the early days were in some measure marked by storm and stress, Lockyer's transparent sincerity and enthusiasm carried him through. When Nature had completed its twenty-fifth year the publishers assembled for a dinner at the Savoy Hotel in Lockyer's honour some fifty of the most active and representative of our scientific men then available. Huxley emerged from retirement to be present. With sly humour he hinted at the chastening, and recalled a story of an aggrieved wife who had received some discipline from her 
husband, but who explained to the magistrate that she "didn't look upon him as a 'usband so much as a friend."

Here I must stop. Otherwise I might touch on Lockyer's kind-heartedness, his capacity for making friends, his courage in family sorrow, his literary labours, and other aspects of a full and many-sided life. I conclude by once more drawing on the jubilee record for the testimony of the Royal Engineers Institute, Chatham, that the Editor of NATURE " never failed to enforce the great lesson that the search for knowledge, pursued for its own ends and with no immediate thoughts of material gain, should be one of the most potent driving forces in the life of a nation."

\section{W. T. Thiselton-Dyer.}

MY acquaintance---and I may add my friendship -with the late Sir Norman Lockyer dates back from almost exactly half a century ago. It began in the autumn of 1870 , when the details of the arrangements in connection with the projected Government expedition to observe the total solar eclipse of December 22 of that year were under consideration. Lockyer was then in the full tide of his intellectual vigour. Two years previously he had leaped into fame, and established a commanding position as one of the pioneers of the newly developed domain of solar physics, by his memorable discovery, made simultaneously with, but independently of, Janssen, of a spectroscopic method of observing, delineating, and analysing the chromosphere at any time the sun is unobscured. In conjunction with Frankland he had detected the existence of a new element in the solar atmosphere named by the discoverers "helium," which Ramsay and others, twentyseven years later, proved to be present in many terrestrial rocks and minerals, and to occur among the gases evolved from springs. Helium, in fact, has been shown to be a widely distributed element, and to be capable of useful application. But with its singular properties, its origin and mode of genesis, and its relations to other "elements," we are not now concerned. The immediate point is that these two cardinal discoveries, with which Lockyer's name will be associated for all time, rendered it a matter of national honour and obligation that every effort should be made, and no opportunity lost, to follow up the line of inquiry he had initiated.

Even although half a century has elapsed; much of the physical history of the sun can be traced only by the observation and study of the phenomena of a total solar eclipse. In 1870 the present methods of attack were, comparatively speaking, in their infancy. Warren de la Rue first used his photo-heliograph during the eclipse of July i8, 1860. In the same year Bunsen constructed the first spectroscope, which was quickly applied to the examination of celestial objects. Tennant had directed it to the corona of the Indian eclipse of I868, and Young to that of the eclipse of 1869 . But the results were contradictory. Tennant found that the spectrum was the ordinary solar specNo. 2653 . VOL. IO67 trum; Young detected the existence of bright lines, but was uncertain as to whether they might not be due to the outlying and nebulous portion of the chromosphere. To the world of science the question was of the greatest interest. Hence the importance of the eclipse of 1870 , which, it was hoped, would settle the matter. Mr. Robert Lowe at that period was Chancellor of the Exchequer, but, even if he were so minded, the Government was unable to resist the appeal of the Royal and Royal Astronomical Societies that properly equipped expeditions should be sent to suitable places along the central line of totality. Lockyer. was by common consent designated as a leader of one of the parties. With characteristic zeal and ardour he threw himself heartily into the work of organisation. Arrangements were made to observe at various stations along the eastern coast of Sicily. He elaborated a comprehensive plan of observation, mainly directed to the elucidation of the structure and physical nature of the corona, and secured the co-operation of competent physicists and trained observers. Unfortunately, all his forethought, labour, and anxiety came to nothing. The Admiralty dispatch-boat Psyche, conveying the party from Naples to Catania, struck a submerged rock near Aci Reale. All on board were safely put on shore, and so, ultimately, were the instruments, but the poor dispatch-boat became a total loss. It was characteristic of Lockyer, whose whole thought was concentrated on the work he had undertaken, that he should have telegraphed home as soon as he reached Catania :-- "Psyche totally wrecked. Instruments saved." Anxious relatives might infer the rest as they pleased.

Misfortune, however, still followed us. We managed to get everything in readiness for the eventful day, but as the total phase approached, the rapid fall of temperature occasioned the formation of cloud; the corona was wholly obscured, and no spectroscopic or other observations during totality were possible, and photographic exposures were useless. The work entrusted to me consisted in determining the photometric intensity of the solar light during the progress of the eclipse, and was independent of the total phase. Fortunately, I was able to obtain a complete set of measurements, which afterwards found their way into one of the publications of the Royal Society. But our philosophy was sorely exercised on learning that a perfect view of the unclouded corona was obtained from the deck of the wrecked Psyche some few miles away. The greatest sympathy was felt by everybody for Lockyer, and his disappointment was naturally very keen. But he bore it stoically; if he had not secured success, he had at least deserved it. Of the band of observers associated with him-among them Sir Henry Roscoe, Sir George Darwin, W. K. Clifford, W. G. Adams, Ranyard, John Brett, the artist, Sir Alexander Pedler, Brothers, Bowen, and Seabroke-I believe I am now the sole survivor.

I was a member of another expedition of which Lockyer was the-leader-viz. that sent to the island of Granada, in the West Indies, to observe 
the total solar eclipse of August 29, I886, when we were generally more fortunate, good observations being made by the late Father Perry, S.J., at Carriacou, Prof. Turner, Savilian professor at Oxford, Sir Arthur Schuster, and Major Darwin. Lockyer was not in good health at the time, and appeared to suffer from the heat and humidity of the climate.

On my translation to the Normal School of Science, South Kensington, as successor to Sir Edward Frankland, I became closely associated with Lockyer as a member of the teaching staff. He lectured on solar physics, and directed the observatory then standing near the western side of Exhibition Road. His laboratory and private room were in the main building close to the chemical laboratories, and I naturally saw much of him at this period. He was an indefatigable experimenter, and I was not infrequently called upon to see his results. He was always ready to discuss his work with anybody who showed an interest in it, and never made the slightest secret of what he was doing and why he was doing it. He was fertile in ideas and prolific in working hypotheses, which were discarded as readily as they were formed if found barren of results. No man ever made a greater scientific use of the imagination, and at times, in the course of conversation, he seemed to give the loosest possible rein to his fancy. Much of his routine observatory work was, of course, done by assistants, by whom he was well served. But he took a very active part in the work of the laboratory, and generally made the crucial observations himself, or assured himself of their validity by repetition. He was an excellent teacher, with a remarkable gift of exposition. He spoke fluently, with a ready command of apt expression and telling phrase, and he had no difficulty in retaining the attention of any audience he addressed. At one period of his career he was in great request as a popular lecturer, and undoubtedly did much to arouse interest and disseminate information concerning celestial phenomena, especially in connection with solar chemistry and physics. He had little opportunity of creating a "school." The primary duty of the Normal School of Science, or, as it was afterwards called, the Royal College of Science, was to train science-teachers, and the subjects of his chair offered little promise of a lucrative career.

He was a loyal colleague, and, under Huxley's wise direction as Dean, took his fair share in discussion and advice. Of his many social gifts others will no doubt be able to testify. He was fond of the society of his fellows, a genial host, entertaining and hospitable, an excellent conversationalist, with a nimble wit, and an unfailing power of ready repartee. There must be very many who have the pleasantest recollections of the delightful dinner parties in his town house in Penywern Road, and of the conversaziones which usually followed them.

Lockyer early enlisted me into the service of NATURE, and I became a frequent contributor to the journal which, under his judicious and enNo. 2653 , VOL. Io6] lightened direction, has done so much to foster and advance the interests of science in this country. My relations with him as the Editor were of the most cordial character, and I collaborated with him occasionally in the production of a lead. ing article. Such work when done in common with him in his sanctum, frequently late at night, necessarily took up much time when protracted, as was usual, by his too ready flow of ideas, which needed a certain power of compression to get them into literary form; and at times it was only in the small hours of the morning that I was able to wend my way home-a not infrequent experience, however, of leader-writers.

It cannot, of course, be maintained that all that Lockyer has published has withstood the test of time. Some of his experimental evidence, and certain of his deductions and generalisations, were hotly challenged at about the time he made them known. But when all is said that can be said in the way of criticism and detraction, it may be confidently asserted that he has left an indelible impress on the scientific history of his epoch. His memory will be cherished by all who have come under his influence, or have learned to appreciate his many excellent qualities of head and heart, and have knowledge of his untiring efforts to serve the highest interests of science.

T. E. ThORPE.

I FIRST made the acquaintance of Lockyer in Clifton, where I met him at dinner at the house of the late William Lant Carpenter in or about 1874. Lockyer had come to give a popular lecture in Bristol on his own and other recent discoveries in celestial spectroscopy, and he was full of his new ideas about the origin and nature of the elements. I remember his asking me whether I considered calcium to be an element, and, having been brought up in the then prevalent view of the permanence of the chemical elements, I replied that I should certainly so regard it. The periodic scheme of Mendeléeff was comparatively new, and Mendeléeff himself did not encourage the notion that it involved the question of the origin of the elements. Lockyer was the first to pursue the subject systematically, and much of his astrophysical research was directed towards establishing his ideas as to the dissociation of the terrestrial elements in the hottest of the stars.

I also remember coming into contact with Lockyer at the time when he was secretary of the Duke of Devonshire's Commission on Scientific Instruction, in the operations of which I was, of course, deeply interested, owing to the position I held as senior science master in Clifton College. I never at that time could have expected to be thrown into daily communication with him, as I was twenty years later, owing to an arrangement with Frankland, then professor of chemistry in the Royal College of Science at South Kensington. Frankland and Lockyer had in 1869 been engaged in joint researches on the "Physical Constitution of the Sun." and when in I88r Lockyer became professor of astrophysics at the Royal 
College of Science he secured the use of a room in the new building to which access was obtainable only through the two intermediate rooms occupied by Frankland and his successors as the research laboratory for chemistry. The consequence was that the professor of astrophysics and his satellites were compelled to pass many times in the day through the chemical rooms. It cannot be said that this was an advantage to the chemical work, for, owing to draughts and general disturbance, some chemical operations were absolutely prohibited; but the arrangement had one compensation in the opportunities afforded of frequent talk with the professor, and of hearing from him what was going on. Lockyer was always very helpful to other less experienced workers with the spectroscope, and after the discovery by Ramsay of terrestrial helium it can be readily imagined what a bustle arose in the room occupied by the professor of astrophysics, to whom the original observation of the same element in the sun was due. This naturally gave rise to many conferences with the professor of chemistry on the subject of the minerals from which the gas was obtained.

Lockyer was also a genial and jovial member of the circle which assembled daily round the luncheon table in the museum, which included in later years some of the professors from the City and Guilds Central College. Nearly all are now gone, and only memories remain to the few survivors. Those recollections include the conviction that Lockyer was a strong man who always knew his own mind, and hence accomplished much both by practice and example where lesser men, though with the same aspirations, only met with failure and disappointment. William A. Tilden.

THE privilege of taking part in the memorial tributes to Sir Norman Lockyer is perhaps something more than I deserve, for, although it is true we were on terms of cordial friendship, we were never associated in official or scientific occupations, unless his invitation to join in the founding of the British Science Guild, and his many courtesies as Editor of NATURE, may be so described. To speak of Lockyer's researches as contributions to science seems inadequate. Incapable as I was of following his scientific work in detail, I felt it to be more than contributory; we admired him rather as a builder, and a builder on big and original lines. There was something large in his undertakings and in his vision, and happily to sustain them he had also within him a fountain of energy which seemed perennial. His prescience and his vigour together were enormous, and carried him into many spheres of activity. If sometimes I was tempted to grudge his spending in the clouds what was needed by mankind, this was ungrateful, for Lockyer put his driving power freely into many sublunary affairs.

That Lockyer was disposed to be combative he was the first to admit, but always on liberal and generous lines; and in personal differences he was always kindly and good-humoured. His was the combativeness that keeps societies from stagnation. On two important affairs he and I differed decisively, but always in good temper, and I gladly admit that in the main he was right on both issues. From the time of.his departure from London most of us had to lament the loss, not, happily, at the time, of an original worker in science, but of a most ingenious and stimulating companion. At length we have lost a colleague not only a master of minute and diligent observation, but also endowed with that wide and abstract imagination which, if other than the individual imagination of the artist, is no less prophetic in the sphere of science.

Clifford Allbutt.

I CANNOT call myself an intimate friend of the late Sir Norman Lockyer, though we frequently met and talked, but two characteristics in him always impressed me. One was his energy. He seemed always to be at work, always to be full of interests, and whatever he took up he did well. The other was the many-sidedness of his mind, and his power of combining business ability and scientific acuteness. Quite early in his career he made important contributions to solar physics, discovering (with Janssen) how to examine the solar prominences apart from an eclipse, investigated meteors, and was one of the three simultaneously to explain the wonderful glows which followed the Krakatoa eruption. Besides this he wrote valuable and suggestive papers on Stonehenge and other British stone circles. With all this he was a very efficient public servant, both in the War Office and in the Science and Art Department, secretary to the Duke of Devonshire's Commission on Scientific Instruction in 1870 , and Editor of NATURE for fifty years from its commencement. We shall not readily meet again with his like.

T. G. Bonney.

Mr. Arthur Savage writes :-Like many other people, I have been reading the life-story of Sir Norman Lockyer, the great man of science who was able to add so liberal a contribution to the accumulation of human knowledge. I was interested to learn from the obituary notice which appeared in the Times of August I 7 that Sir Norman was the founder of NATURE, and I have thought the opportunity a fitting one to express a young man's humble word of appreciation of your excellent journal.

Although I have not received a university education, and my daily duties are outside the domain of scientific study, you may be glad to know that I follow your columns regularly in order to keep myself "up to date" in matters relating to those branches of knowledge in which I am interested. Should you consider this note worthy of publication I have no doubt that it would represent the feelings of numerous other "ordinary" individuals like myself. 